\title{
INFLUENCE OF PHOSPHORUS LEVELS ON GROWTH AND YIELD OF FOUR LENTIL VARIETIES
}

\author{
R.A. Sonet, M.H. Ali, A.K.M.R. Amin, M.N. Haque and S.M. Masum \\ Department of Agronomy, Sher-e-Bangla Agricultural University, Sher-e-Bangla Nagar, Dhaka-1207, Bangladesh \\ Corresponding E-mail: smmasum607@yahoo.com
}

(Received: 23 April, 2020, Accepted: 07 June, 2020)

Keywords: Lentil, phosphorus, variety, nodule, AEZ 28

\begin{abstract}
An adequate supply of phosphorus $(\mathrm{P})$ is important for the proper growth and yield of lentil, particularly in poor fertile soil. As such an experiment was carried out to evaluate the effects of phosphorus (P) fertilizer application on growth, yield, and yield components of lentil at the agronomy research field of Sher-e-Bangla Agricultural University, Dhaka, Bangladesh during 2013-201. Four lentil varieties (BARI Masur-4, BARI Masur-5, BARI Masur-6, and BARI Masur-7) and four levels of $\mathrm{P}\left(0,20,40\right.$ and $\left.60 \mathrm{~kg} \mathrm{P}_{2} \mathrm{O}_{5} \mathrm{ha}^{-1}\right)$ were used in this experiment as treatment variables. Interaction of cultivar and $\mathrm{P}$ levels showed a significant influence on all the plant characters studied except plant height and branch production. The highest seed yield $\left(1.98 \mathrm{t} \mathrm{ha}^{-1}\right)$ was obtained from the combination of BARI Masur-7 with $40 \mathrm{~kg} \mathrm{P} \mathrm{O}_{5} \mathrm{ha}^{-1}$, and the lowest $\left(1.08 \mathrm{t} \mathrm{ha}^{-1}\right)$ was from BARI Masur-5 with $0 \mathrm{~kg}$ $\mathrm{P}_{2} \mathrm{O}_{5}$ ha $^{-1}$. Addition of $\mathrm{P}$ fertilizer beyond $40 \mathrm{~kg} \mathrm{ha}{ }^{-1}$ decreased seed yield irrespective of varieties. Results revealed that the application of $P$ fertilizer offers a large scope for obtaining a higher yield of lentil in Bangladesh. However, the application of $\mathrm{P}$ fertilizer at the rate of $40 \mathrm{~kg} \mathrm{P}_{2} \mathrm{O}_{5}$ ha $^{-1}$ would be the optimum for achieving higher yield irrespective of varieties.
\end{abstract}

\section{Introduction}

Pulses are the basic component of a cropping pattern in Bangladesh as these crops suitable in crop rotation and diversified or intercropping systems followed under different agro-ecological regions. Lentil (Lens culinaris Medik) locally known as Masoor, is an important winter crop that has been grown as an important pulse for over 8,000 years (Dhuppar et al., 2012). In Bangladesh, lentil placed first position among the pulses in 154680.56 hectares, and production MT168837 (BBS, 2017). Lentil share a rich source of dietary protein, macronutrients, micronutrients ( $\mathrm{Fe}, \mathrm{Zn}$ and $\mathrm{Se}$ ), and vitamins for poor consumers who cannot afford animal products due to high prices. Despite its importance, the production of lentil in Bangladesh is characterized by low mean yield of $1.27 \mathrm{t} \mathrm{ha}^{-1}$ (BBS, 2017) due to lack of improved variety. Furthermore, variety plays an important role in producing a high yield of lentil because different varieties responded differently for their genotypic characters (Hussain et al., 2002). Among different released varieties of lentil in Bangladesh: BARI Masur-4, BARI Masur-5, BARI Masur-6, and BARI Masur-7 are mentionable for high yield potential and quality.

Phosphorus $(\mathrm{P})$ is a non-renewable and second most important macronutrient which is required for young tissues and performs several functions related to growth, development, and metabolism of the plant and also regulates many metabolic activities of the plant life. Phosphorus increases the hardiness of the crop and an adequate supply of phosphorus results in rapid 
growth (Singh and Singh, 2016). Phosphorus is the key element for successful pulse production because it is involved in root development, stalk and stem strength, flower and seed formation, crop maturity and production, N-fixation, crop quality and resistance to plant diseases by enhancing the physiological functions. It plays an important role to stimulate biological activities like nodulation, nitrogen fixation, and nutrient uptake in soil and rhizosphere environment resulting in a higher yield of legume crops (Khanam et al., 2016). The effect of phosphorus fertilization was significant on the number of pods plant ${ }^{-1}$ and grain yield (Singh et al., 2003). The optimum phosphorus application enhances the yield attributes such as the number of pods plant $^{-1}$, grains pod ${ }^{-1}$ and 1000-seed weight, resulting in high production (Singh and Singh, 2016).

Farmers usually grow lentil without any fertilizer. Lentil suffering from $\mathrm{P}$ deficiency stimulates the length of the primary root, length and number of lateral roots and root hairs (Sarker and Karmoker, 2009), the increment in lateral roots was more than the primary root and resulted to increase in root surface area. The increase in the root surface area enhances the phosphorus acquisition from phosphorus-deficient soils, however, the varieties having prolific root hair formation are better in the acquisition of those nutrients $(\mathrm{P}, \mathrm{K}, \mathrm{Fe}, \mathrm{Mn}, \mathrm{Cu}, \mathrm{Zn}, \mathrm{Mo})$ which are less available in soil (Gahoonia et al., 2006). The majority of soils under lentil cultivation in AEZ 28 of Bangladesh are low to medium in available phosphorus, therefore, they respond well to the recommended level of phosphorus fertilizers (Shil et al., 2016; Rashid et al., 2018). There was, therefore, a need to study the effect of $\mathrm{P}$ fertilizer levels on the growth and yield of lentil genotypes.

\section{Materials and Methods}

The field experiment was conducted at the research field of the Agronomy Department, Sher-eBangla Agricultural University, Dhaka (Tejgaon series under AEZ 28) during the period December 2013 to April 2014. The experimental site was located at 2377' $\mathrm{N}$ latitude and $90^{\circ} 3^{\prime}$ E longitude with an elevation of $4.0 \mathrm{~m}$ from the sea level. The temperature during the cropping period ranged between $17.0^{\circ} \mathrm{C}$ to $26.9^{\circ} \mathrm{C}$, the humidity $58.66 \%$ to $80.25 \%$ with 10.5-11.0 hours day length, and very little rainfall was recorded. The soil of the experimental site was silt loam in texture, with $\mathrm{pH} 6.4$, organic carbon $0.68 \%$, total nitrogen $0.08 \%$, available phosphorus $10.99 \mathrm{mgkg}^{-1}$, available potassium 0.05 meq100 $\mathrm{g}^{-1}$ and available sulphur 10.5 $\mathrm{mgkg}^{-1}$. The climate of this area is subtropical with average monthly maximum and minimum temperature, rainfall, relative humidity of $27.34{ }^{\circ} \mathrm{C}$ and $16.04{ }^{\circ} \mathrm{C}, 62.34 \mathrm{~mm}, 66.53 \%$, respectively. Four lentil varieties $\left(\mathrm{V}_{1}=\right.$ BARI Masur- $4, \mathrm{~V}_{2}=$ BARI Masur-5, $\mathrm{V}_{3}=$ BARI Masur-6, $\mathrm{V}_{4}=$ BARI Masur-7) and four levels of phosphorus $\left(\mathrm{P}_{0}=0 \mathrm{~kg} \mathrm{P} \mathrm{O}_{5}\right.$ ha-1, $\mathrm{P}_{1}=20 \mathrm{~kg} \mathrm{P}_{2} \mathrm{O}_{5}$ ha $^{-1}$,

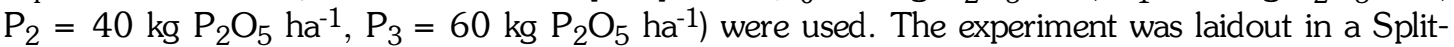
plot design with three replications. Different varieties of lentils were in the main plot and different levels of phosphorus in sub-plot. In this experiment phosphorus was applied as per treatment and urea (175 kg ha $\left.{ }^{-1}\right)$, MoP (125 kg ha-1), gypsum (75 kg ha-1) were used as a recommended doses (FRG, 2012). The whole amount of all fertilizers except $P$ was applied as basal dose (during final land preparation). Rate of $\mathrm{P}$ in the form of Triple Super Phosphate (TSP) was used as per treatment and applied as a basal dose. Sowing was done on 18 November 2013 in continuous rows at the rate of $35 \mathrm{~kg} \mathrm{ha}^{-1}$. After sowing the seeds were covered with soil, slightly pressed by hand. The maturity of the crop was determined when $95 \%$ of the pods become brown. The data collected on different parameters were statistically analyzed and significant differences among the treatment means were compared by Duncan's Multiple Range Test (DMRT) at 5\% level of probability (Gomez and Gomez, 1984). 


\section{Results and Discussion}

\section{Plant height}

Plant height is a useful growth index that influences dry matter production and yield. Although plant height is controlled genetically it may be modified by different agronomic practices. Plant height was significantly influenced by variety and levels of phosphorus at 15 and 60 DAS but showed a non-significant effect at 30,45, 75, and 90 DAS (Table 1). The plant height of lentil increased significantly up to $60 \mathrm{~kg} \mathrm{P}_{2} \mathrm{O}_{5} \mathrm{ha}^{-1}$. Variations in plant height due to varieties were also reported by Hasan et al. (2015) and Datta et al. (2013). Increment in plant height might be due to the stimulation of biological activities in the presence of a balanced supply of phosphorus. Similar results on the increased plant height with an increased level of phosphorus application have also been reported by other researchers (Barua et al., 2011; Datta et al., 2013).

Table 1. Effect of variety and phosphorus on plant height of lentil at different days after sowing (DAS)

\begin{tabular}{|c|c|c|c|c|c|c|c|}
\hline \multirow{2}{*}{\multicolumn{2}{|c|}{$\begin{array}{c}\text { Variety } \mathrm{P}_{2} \mathrm{O}_{5} \text { level } \\
\left(\mathrm{kg} \mathrm{ha}^{-1}\right)\end{array}$}} & \multicolumn{6}{|c|}{ Plant height $(\mathrm{cm})$ at } \\
\hline & & \multirow{2}{*}{$\frac{15 \text { DAS }}{10.57 \mathrm{a}-\mathrm{c}}$} & \multirow{2}{*}{$\frac{30 \text { DAS }}{12.52}$} & \multirow{2}{*}{$\frac{45 \text { DAS }}{17.70}$} & \multirow{2}{*}{$\begin{array}{c}60 \text { DAS } \\
19.47 b\end{array}$} & \multirow{2}{*}{$\frac{75 \text { DAS }}{27.67}$} & \multirow{2}{*}{$\frac{90 \text { DAS }}{29.10}$} \\
\hline BARI Masur-4 & 0 & & & & & & \\
\hline & 20 & $10.57 \mathrm{a}-\mathrm{c}$ & 12.57 & 19.83 & $27.87 \mathrm{ab}$ & 29.40 & 31.77 \\
\hline & 40 & $11.55 \mathrm{a}-\mathrm{c}$ & 12.30 & 20.43 & $27.07 \mathrm{ab}$ & 30.20 & 32.07 \\
\hline & 60 & $10.83 a-c$ & 13.17 & 20.00 & $31.67 \mathrm{a}$ & 30.97 & 32.07 \\
\hline \multirow[t]{4}{*}{ BARI Masur-5 } & 0 & $10.77 \mathrm{a}-\mathrm{c}$ & 12.47 & 17.53 & $25.17 \mathrm{ab}$ & 26.87 & 29.97 \\
\hline & 20 & $10.20 \mathrm{bc}$ & 12.53 & 19.27 & $27.63 \mathrm{ab}$ & 29.07 & 30.17 \\
\hline & 40 & 10.89 a-c & 13.50 & 20.17 & $26.73 \mathrm{ab}$ & 29.07 & 31.17 \\
\hline & 60 & $11.33 \mathrm{a}-\mathrm{c}$ & 14.93 & 21.13 & $25.77 \mathrm{ab}$ & 30.73 & 31.53 \\
\hline \multirow[t]{4}{*}{ BARI Masur-6 } & 0 & $10.53 \mathrm{a}-\mathrm{c}$ & 12.67 & 19.43 & $25.97 \mathrm{ab}$ & 27.30 & 26.97 \\
\hline & 20 & $10.13 \mathrm{c}$ & 12.37 & 19.40 & $27.43 \mathrm{ab}$ & 27.40 & 28.17 \\
\hline & 40 & $10.77 \mathrm{a}-\mathrm{c}$ & 12.67 & 19.63 & $27.30 \mathrm{ab}$ & 28.43 & 30.43 \\
\hline & 60 & $10.63 \mathrm{a}-\mathrm{c}$ & 12.47 & 19.67 & $27.17 \mathrm{ab}$ & 28.63 & 30.53 \\
\hline \multirow[t]{4}{*}{ BARI Masur-7 } & 0 & $12.60 \mathrm{a}$ & 12.87 & 19.83 & $27.10 \mathrm{ab}$ & 29.17 & 26.53 \\
\hline & 20 & $11.50 \mathrm{a}-\mathrm{c}$ & 14.50 & 20.07 & $27.40 \mathrm{ab}$ & 31.43 & 29.50 \\
\hline & 40 & $12.30 \mathrm{ab}$ & 12.83 & 20.97 & $29.97 \mathrm{a}$ & 30.97 & 31.40 \\
\hline & 60 & $10.83 a-c$ & 14.50 & 21.23 & $27.40 \mathrm{ab}$ & 32.87 & 31.63 \\
\hline $\mathrm{SE}_{(0.05)}$ & & 0.61 & 1.18 & 1.39 & 2.45 & 1.74 & 1.76 \\
\hline $\mathrm{CV}(\%)$ & & 9.65 & 15.60 & 12.22 & 15.78 & 10.28 & 10.09 \\
\hline
\end{tabular}

Any two means not sharing the same letter differ significantly at 5\% level of probability (DMRT)

\section{Nodule number plant ${ }^{-1}$}

Nodule production plant ${ }^{-1}$ was significantly influenced by varieties and different levels of phosphorus at 15, 30, 45, 60, 75, and 90 days after sowing (Table 2). At 60 days after sowing the highest number of the nodules plant ${ }^{-1}$ (13.33) was found from the combination of BARI Masur-6 with60 kg $\mathrm{P}_{2} \mathrm{O}_{5}$ ha $^{-1}$. At 15 days the lowest number of the nodules plant ${ }^{-1}(0.333)$ was found from BARI Masur-4 with $0 \mathrm{~kg} \mathrm{P}_{2} \mathrm{O}_{5}$ ha $^{-1}$. The number of nodules increases as the plant grows, and normally reaches the maximum at the mid flowering stage when the plant needs $\mathrm{N}$ the most (Jindal et al., 2008). Datta et al. (2013) observed that numbers of nodule production in lentil increase with the increasing the phosphorus level. The symbiotic parameters i.e. nodulation, nodule dry weight, and leghaemoglobin content are positively influenced by phosphorus application (Rashid et al., 2018). So, proper application of $\mathrm{P}$ to lentil facilitates the 
earlier formation of nodules, increasing their numbers which enhances the nitrogen fixation (Gahoonia et al., 2006). Thus, $\mathrm{P}$ increases the yield of lentil by stimulating physiological functions and root development that improve nodulation (Sharma and Sharma, 2004). The increasing dose of $\mathrm{P}$ from 20 to $60 \mathrm{~kg} \mathrm{P}_{2} \mathrm{O}_{5} \mathrm{ha}^{-1}$ increased the nodules and their dry weight per plant (Jindal et al., 2008). The number of nodules per plant declined at the highest dose (80 kg ha $^{-1}$ ) of $\mathrm{P}$ (Rasheed et al., 2010).

\section{Effective branches plant ${ }^{-1}$}

The number of effective branches plant $^{-1}$ is one of the most important yield contributing characters in lentil. Effective branches plant ${ }^{-1}$ was significantly influenced by variety and different levels of phosphorus applications (Table 3). The highest number of effective branches plant ${ }^{-1}$ (8.00) was found from BARI Masur-7 with $40 \mathrm{~kg} \mathrm{P}_{2} \mathrm{O}_{5} \mathrm{ha}^{-1}$ and the lowest number of effective branches (4.00) from BARI Masur-5 with $0 \mathrm{~kg} \mathrm{P} \mathrm{O}_{5} \mathrm{ha}^{-1}$. Patil et al. (2003) and Hussain et al. (2002) also reported that effective branches plant ${ }^{-1}$ also vary with variety and different levels of $P$.

Table 2. Effect of variety and phosphorus on nodule production of lentil at different DAS

\begin{tabular}{|c|c|c|c|c|c|c|c|}
\hline \multirow{2}{*}{\multicolumn{2}{|c|}{$\begin{array}{cc}\text { Variety } & \mathrm{P}_{2} \mathrm{O}_{5} \text { level } \\
\left(\mathrm{kg} \mathrm{ha}^{-1}\right)\end{array}$}} & \multicolumn{6}{|c|}{ Number of nodules plant ${ }^{-1}$ at } \\
\hline & & \multirow{2}{*}{$\frac{15 \text { DAS }}{0.33 \mathrm{~d}}$} & \multirow{2}{*}{$\frac{30 \text { DAS }}{1.00 \mathrm{c}}$} & \multirow{2}{*}{$\begin{array}{c}45 \text { DAS } \\
2.00 \mathrm{~b}\end{array}$} & \multirow{2}{*}{$\begin{array}{l}60 \mathrm{DAS} \\
6.00 \mathrm{~cd}\end{array}$} & \multirow{2}{*}{$\frac{75 \text { DAS }}{4.33 \mathrm{de}}$} & \multirow{2}{*}{$\frac{90 \mathrm{DAS}}{2.67 \mathrm{fg}}$} \\
\hline BARI Masur-4 & 0 & & & & & & \\
\hline & 20 & $1.33 \mathrm{a}-\mathrm{d}$ & $1.67 \mathrm{bc}$ & $2.33 \mathrm{ab}$ & $8.33 \mathrm{bc}$ & $5.33 \mathrm{~b}-\mathrm{e}$ & $4.33 \mathrm{c}-\mathrm{g}$ \\
\hline & 40 & $2.33 \mathrm{a}$ & $2.67 \mathrm{a}$ & $2.67 \mathrm{ab}$ & $10.67 \mathrm{ab}$ & 5.33 b-e & $5.00 \mathrm{~b}-\mathrm{g}$ \\
\hline & 60 & $1.67 \mathrm{a}-\mathrm{c}$ & $1.67 \mathrm{bc}$ & $2.67 \mathrm{ab}$ & $11.67 \mathrm{ab}$ & $7.67 \mathrm{a}-\mathrm{c}$ & $7.00 \mathrm{a}-\mathrm{c}$ \\
\hline \multirow[t]{4}{*}{ BARI Masur-5 } & 0 & $0.67 \mathrm{~cd}$ & $1.33 \mathrm{bc}$ & $2.00 \mathrm{~b}$ & $2.67 e$ & $3.33 e$ & $3.33 \mathrm{e}-\mathrm{g}$ \\
\hline & 20 & $1.00 \mathrm{~b}-\mathrm{d}$ & $1.00 \mathrm{c}$ & $2.67 \mathrm{ab}$ & $3.67 \mathrm{de}$ & $5.00 \mathrm{c}-e$ & $4.00 \mathrm{~d}-\mathrm{g}$ \\
\hline & 40 & $1.67 \mathrm{a}-\mathrm{c}$ & $2.00 \mathrm{ab}$ & $2.67 \mathrm{ab}$ & $6.33 \mathrm{~cd}$ & 6.33 a-e & $4.67 c-g$ \\
\hline & 60 & $1.67 \mathrm{a}-\mathrm{c}$ & $2.00 \mathrm{ab}$ & $2.67 \mathrm{ab}$ & $9.00 \mathrm{bc}$ & 7.33 a-d & $5.33 \mathrm{~b}-\mathrm{f}$ \\
\hline \multirow[t]{4}{*}{ BARI Masur-6 } & 0 & $0.67 \mathrm{~cd}$ & $1.33 \mathrm{bc}$ & $2.33 \mathrm{ab}$ & $8.33 b c$ & 5.33 b-e & $2.33 \mathrm{~g}$ \\
\hline & 20 & $1.33 \mathrm{a}-\mathrm{d}$ & $1.67 \mathrm{bc}$ & $1.67 \mathrm{~b}$ & $11.33 \mathrm{ab}$ & 6.00 a-e & $4.33 c-g$ \\
\hline & 40 & $2.00 \mathrm{ab}$ & $2.00 \mathrm{ab}$ & $2.33 \mathrm{ab}$ & $11.33 \mathrm{ab}$ & 6.00 a-e & $6.33 \mathrm{a}-\mathrm{d}$ \\
\hline & 60 & $2.00 \mathrm{ab}$ & $2.00 \mathrm{ab}$ & $3.33 \mathrm{a}$ & $13.33 \mathrm{a}$ & $8.33 \mathrm{ab}$ & $7.67 \mathrm{ab}$ \\
\hline \multirow[t]{4}{*}{ BARI Masur-7 } & 0 & $1.33 \mathrm{a}-\mathrm{d}$ & $1.67 \mathrm{bc}$ & $1.67 \mathrm{~b}$ & $4.00 \mathrm{de}$ & $5.00 \mathrm{c}-e$ & $2.33 \mathrm{~g}$ \\
\hline & 20 & $2.00 \mathrm{ab}$ & $2.00 \mathrm{ab}$ & $2.33 \mathrm{ab}$ & $6.33 \mathrm{~cd}$ & $7.67 \mathrm{a}-\mathrm{c}$ & 5.67 b-e \\
\hline & 40 & $1.67 \mathrm{a}-\mathrm{c}$ & $2.00 \mathrm{ab}$ & $2.67 \mathrm{ab}$ & $10.00 \mathrm{ab}$ & $8.00 \mathrm{a}-\mathrm{c}$ & $6.67 \mathrm{a}-\mathrm{d}$ \\
\hline & 60 & $1.67 \mathrm{a}-\mathrm{c}$ & $1.67 b c$ & $3.33 \mathrm{a}$ & $10.00 \mathrm{ab}$ & $8.67 \mathrm{a}$ & $8.67 \mathrm{a}$ \\
\hline $\mathrm{SE}_{(0.05)}$ & & 0.304 & 0.236 & 0.323 & 1.042 & 0.923 & 0.835 \\
\hline CV (\%) & & 36.14 & 23.61 & 22.74 & 21.71 & 25.66 & 28.80 \\
\hline
\end{tabular}

Any two means not sharing the same letter differ significantly at $5 \%$ level of probability (DMRT)

\section{Number of filled pods plant ${ }^{-1}$}

Pods plant ${ }^{-1}$ is an important parameter determining the seed yield of the crop. It is clear from the data given in Table 3 that number of filled pods plant ${ }^{-1}$ was significantly influenced by the combination of varieties and different levels of phosphorus application. The highest number of filled pod plant ${ }^{-1}$ (73.0) was found from BARI Masur-7 with $40 \mathrm{~kg} \mathrm{P}_{2} \mathrm{O}_{5}$ ha $^{-1}$ and the lowest filled pod plant ${ }^{-1}$ (26.33) from BARI Masur-5 with $0 \mathrm{~kg} \mathrm{P}_{2} \mathrm{O}_{5} \mathrm{ha}^{-1}$. Datta et al. (2013) mentioned that numbers of pod in lentil significantly varied due to variations of variety and $P$ levels. It might be the reason for moderate plant nutrients availability due to which the plant produces more pods plant $^{-1}$ as compare to other treatments and also phosphorus strongly 
increases the reproduction of the plants i.e. flowering and fruiting. Furthermore, $\mathrm{P}$ fertilization might stimulate the plant for flowering and fruiting which leads to producing more pods (Maqsood et al., 2000).

\section{Number of seeds pod $^{-1}$}

The number of seeds pod $^{-1}$ is also an important yield contributing parameter which has a great effect on final yield. It was observed that the treatment combination of variety and phosphorus had a significant effect on number of seeds $\operatorname{pod}^{-1}$ (Table 3). The highest number of seeds pod ${ }^{-1}$ (1.97) was found for the treatment BARI Masur-6 with $40 \mathrm{~kg} \mathrm{P}_{2} \mathrm{O}_{5} \mathrm{ha}^{-1}$ and BARI Masur-7 with $40 \mathrm{~kg} \mathrm{P} \mathrm{O}_{5}$ ha $^{-1}$ while the lowest number of seeds pod ${ }^{-1}$ (1.64) from BARI Masur-4 with $0 \mathrm{~kg}$ $\mathrm{P}_{2} \mathrm{O}_{5} \mathrm{ha}^{-1}$. The used plant materials are the modern variety of lentils in Bangladesh therefore variation was mainly due to application of different phosphorus levels. Hussain et al. (2002) reported that the number of seed pod $^{-1}$ varied greatly with varieties in lentil. Zeidan (2007) reported that increasing phosphorus levels from 0 to $60 \mathrm{~kg}$ increased seeds pod ${ }^{-1}$. The numbers of seeds pod ${ }^{-1}$ are enhanced with a successive increase in P levels from 20 to 40 and $60 \mathrm{~kg} \mathrm{ha}^{-1}$ (Choubey et al., 2013). The increment in $\mathrm{P}$ accumulates the photosynthesis from growing organs to seeds leading to make them plump and bold, thus affect the seed size and weight. Hence, seeds pod $^{-1}$ can be improved by superior $\mathrm{P}$ fertilization.

\section{0-seed weight}

Seed weight is an important quality parameter of crops which has a great effect on final yield. Although this character is genetically controlled, the growing condition also exerts considerable influence on its expression. It is observed that the treatment combination of variety and phosphorus had a significant effect on 1000-seed weight (Table 3). The highest 1000-seed weight $(26.67 \mathrm{~g})$ was found from BARI Masur-6 with $40 \mathrm{~kg} \mathrm{P}_{2} \mathrm{O}_{5} \mathrm{ha}^{-1}$ whereas the lowest (20.33 g) from BARI Masur-4 with $0 \mathrm{~kg} \mathrm{P}_{2} \mathrm{O}_{5} \mathrm{ha}^{-1}$.

Table 3. Effect of variety and phosphorus on yield contributing parameters and yield of lentil

\begin{tabular}{|c|c|c|c|c|c|c|}
\hline $\begin{array}{r}\text { Variety } P \\
(\mathrm{~kg} \\
\mathrm{h}\end{array}$ & level & $\begin{array}{c}\text { Effective } \\
\text { branch plant }{ }^{-1}\end{array}$ & $\begin{array}{l}\text { Filled pods } \\
\text { plant }^{-1}\end{array}$ & $\begin{array}{l}\text { Seeds } \\
\text { pod }^{-1}\end{array}$ & $\begin{array}{l}1000 \text {-seed } \\
\text { weight }\end{array}$ & $\begin{array}{l}\text { Seed yield } \\
\left(\mathrm{t} \mathrm{ha}^{-1}\right)\end{array}$ \\
\hline BARI Masur-4 & 0 & $4.33 \mathrm{fg}$ & $35.00 \mathrm{~d}-\mathrm{f}$ & $1.64 \mathrm{~b}$ & $20.33 c$ & $1.11 \mathrm{de}$ \\
\hline & 20 & $5.33 \mathrm{~d}-\mathrm{g}$ & $53.00 \mathrm{~b}-\mathrm{d}$ & $1.77 \mathrm{ab}$ & $21.33 \mathrm{a}-\mathrm{c}$ & $1.48 c-e$ \\
\hline & 40 & 6.33 a-e & $61.00 \mathrm{a}-\mathrm{c}$ & $1.91 \mathrm{ab}$ & $26.33 \mathrm{ab}$ & $1.56 \mathrm{bc}$ \\
\hline & 60 & 6.33 a-e & $55.67 \mathrm{a}-\mathrm{c}$ & $1.78 \mathrm{ab}$ & $23.67 \mathrm{a}-\mathrm{c}$ & $1.51 \mathrm{~cd}$ \\
\hline BARI Masur-5 & 0 & $4.00 \mathrm{~g}$ & $26.33 \mathrm{f}$ & $1.66 \mathrm{ab}$ & $21.33 \mathrm{a}-\mathrm{c}$ & $1.08 e$ \\
\hline & 20 & $5.00 e^{-g}$ & $48.67 \mathrm{c}-\mathrm{e}$ & $1.74 \mathrm{ab}$ & $21.67 \mathrm{a}-\mathrm{c}$ & $1.42 \mathrm{c}-\mathrm{e}$ \\
\hline & 40 & $6.00 \mathrm{~b}-\mathrm{f}$ & $62.67 \mathrm{a}-\mathrm{c}$ & $1.90 \mathrm{ab}$ & 25.33 a-c & $1.54 \mathrm{bc}$ \\
\hline & 60 & $5.67 \mathrm{c}-\mathrm{g}$ & $55.00 \mathrm{a}-\mathrm{c}$ & $1.75 \mathrm{ab}$ & $21.33 \mathrm{a}-\mathrm{c}$ & $1.44 c-e$ \\
\hline BARI Masur-6 & 0 & $5.67 c-g$ & 33.00 ef & $1.74 \mathrm{ab}$ & $21.00 \mathrm{bc}$ & $1.37 \mathrm{c}-\mathrm{e}$ \\
\hline & 20 & 6.67 a-e & 51.33 b-e & $1.93 \mathrm{ab}$ & $23.00 \mathrm{a}-\mathrm{c}$ & $1.74 \mathrm{a}-\mathrm{c}$ \\
\hline & 40 & $7.33 \mathrm{a}-\mathrm{c}$ & $68.67 \mathrm{ab}$ & $1.97 \mathrm{a}$ & $26.67 \mathrm{a}$ & $1.79 \mathrm{a}-\mathrm{c}$ \\
\hline & 60 & $7.00 \mathrm{a}-\mathrm{d}$ & $54.00 \mathrm{a}-\mathrm{d}$ & $1.71 \mathrm{ab}$ & $24.00 \mathrm{a}-\mathrm{c}$ & $1.79 \mathrm{a}-\mathrm{c}$ \\
\hline BARI Masur-7 & 0 & $5.33 \mathrm{~d}-\mathrm{g}$ & $35.67 \mathrm{~d}-\mathrm{f}$ & $1.69 \mathrm{ab}$ & $22.00 \mathrm{a}-\mathrm{c}$ & $1.39 \mathrm{c}-\mathrm{e}$ \\
\hline & 20 & $7.33 \mathrm{a}-\mathrm{c}$ & $53.00 \mathrm{~b}-\mathrm{d}$ & $1.89 \mathrm{ab}$ & $22.00 \mathrm{a}-\mathrm{c}$ & $1.73 \mathrm{a}-\mathrm{c}$ \\
\hline & 40 & $8.00 \mathrm{a}$ & $73.00 \mathrm{a}$ & $1.97 \mathrm{a}$ & $26.00 \mathrm{ab}$ & $1.98 \mathrm{a}$ \\
\hline & 60 & $7.67 \mathrm{ab}$ & $53.67 \mathrm{~b}-\mathrm{d}$ & $1.91 \mathrm{ab}$ & $25.33 \mathrm{a}-\mathrm{c}$ & $1.95 \mathrm{ab}$ \\
\hline $\mathrm{SE}_{(0,05)}$ & & 0.569 & 5.734 & 0.095 & 0.124 & 0.124 \\
\hline $\mathrm{CV}(\%)$ & & 16.08 & 19.39 & 9.02 & 13.73 & 13.73 \\
\hline
\end{tabular}

Any two means not sharing the same letter differ significantly at $5 \%$ level of probability (DMRT) 
Variation in 1000-seed weight in different varieties was also reported by Datta et al. (2013) in lentil. Saxena and Varma (1996) also obtained a significant effect on 1000-seed weight and the highest was recorded from 30 to $60 \mathrm{~kg} \mathrm{P}_{2} \mathrm{O}_{5}$ ha $^{-1}$ which is conformity with the present results. In lentil increasing level of $\mathrm{P}$ from 20 to $80 \mathrm{~kg} \mathrm{ha}^{-1}$ significantly increase the time of field maturity (Rasheed et al., 2010) because $\mathrm{P}$ stimulates the nitrogenase activity of root nodules and physiological processes (Khan et al., 2006). So, higher $\mathrm{P}$ rates application lengthen the period of crop maturity and consequently increase the seed yield, by improving 1000-seed weight (Rasheed et al., 2010).

\section{Seed yield}

Seed yield is the output of different treatments applied as well as the effect of different agronomic practices and the environment. The variation in seed yield might be due to differences in yield attributing parameters like the number of pods plant ${ }^{-1}$, seeds pod $^{-1}$, and test weight among the varieties which are influenced by the phosphorus fertilizer application (Table 3). The yield varied from 1.08 to $1.98 \mathrm{t} \mathrm{ha}^{-1}$ due to different levels of $\mathrm{P}$ and varieties. The highest seed yield (1.98 t ha-1) was found from BARI Masur-7 with $40 \mathrm{~kg} \mathrm{P}_{2} \mathrm{O}_{5} \mathrm{ha}^{-1}$. However, the increase in seed yield of BARI Masur-4, BARI Masur-5, BARI Masur- 6 and BARI Masur-7 were 40,43, 31 and 43\%, respectively compared to the controls. This indicates the fact that agronomic biofortification may have fostered the photosynthesis process and translocation of photosynthetic products to the seed as a result of an increase in enzymatic activity (Islam et al., 2018). An increase in phosphorus fertilizer beyond $40 \mathrm{~kg} \mathrm{ha}^{-1}$ tended to decrease seed yield irrespective of varieties. This might be due to the imbalance of other nutrients. Similar findings were also obtained by Singh et al. (2005) who reported that increased phosphorus application demonstrated a higher yield of lentil at a certain level.

\section{Conclusion}

The agronomic biofortification had influenced the plant height, branch plant ${ }^{-1}$, and importantly, the number of nodules plant ${ }^{-1}$. So, optimum management of $\mathrm{P}$ is necessary to harvest the full potential of the lentil crop cultivated on low to medium $\mathrm{P}$ status soils. The combination effect revealed that lentil var. BARI Masur-7 with $40 \mathrm{~kg} \mathrm{P}_{2} \mathrm{O}_{5}$ ha-1 performed best in producing a higher seed yield. Therefore, it could be concluded that var. BARI Masur-7 with $40 \mathrm{~kg} \mathrm{P}_{2} \mathrm{O}_{5}$ ha $^{-}$

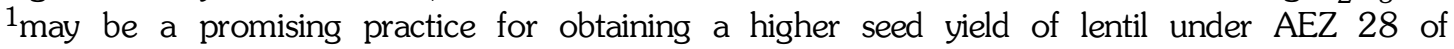
Bangladesh.

\section{References}

Barua, R., M.S.U. Bhuiya, M.M. Kabir, S. Maniruzzamanand Z. Ahmed. 2011. Effects of mimosa (Mimosa invisa) compost and phosphorus on the yield and yield components of lentil (Lens culinaris L.). The Agriculturists. 9: 63-72.

BBS (Bangladesh Bureau of Statistics). 2017. Yearbook of Agricultural Statistics. Statistics and Information Division, Ministry of Planning. Government of the People's Republic of Bangladesh, Dhaka-1207.

Choubey, S.K., V.P. Dwivedi and N.K. Srivastava. 2013. Effect of different levels of phosphorus and sulphur on growth, yield and quality of lentil (Lens culinaris M). Indian J. Sci. Res. 4: 149150.

Datta, S.K., M.A.R. Sarkar and F.M.J. Uddin. 2013. Effect of variety and level of phosphorus on the yield and yield components of lentil. Intl. J. Agril. Res. Innov. Tech. 3(1): 78-82. 
Dhuppar, P., S. Biyan, B. Chintapalli and S. Rao. 2012. Lentil crop production in the context of climate change: An Appraisal. Indian Res. J. Ext. Edu. 2(Special Issue): 33-35.

FRG (Fertilizer Recommendation Guide). 2012. Bangladesh Agricultural Research Council, Khamarbari, Farmgate, Dhaka. p.31.

Gahoonia, T.S., O. Ali, A. Sarker, N.E. Nielsen and M.M. Rahman. 2006. Genetic variation in root traits and nutrient acquisition of lentil genotypes. J. Plant Nutr. 29: 643-655.

Gomez, K.A. and A.A. Gomez. 1984. Statistical Procedure for Agricultural Research (2nd ed.). International Rice Research Institute. Jhon Wiley and sons, Inc. Singapore. pp.139-240.

Hasan, A.K., M. Ashiquzzaman, Q.F. Quadir and I. Ahmed. 2015. Phosphorus use efficiency of different varieties of lentil and grasspea. Res. Agric. Livest. Fish. 2(2): 271-277.

Hussain, M., S.H. Shah and S.M. Nazir. 2002. Differential genotypic response to phosphorus application in lentil (Lens culinaris Medic). Intl. J. Agric. Biol. 4: 61-63.

Islam, M.M., M.R. Karim, M.M.H. Oliver, T.A. Urmi, M.A. Hossain and M.M. Haque. 2018. Impacts of trace element addition on lentil (Lens culinaris L.) agronomy. Agron. 8: 100, doi: 10.3390/agronomy8070100.

Jindal, C., V. Khanna and P. Sharma. 2008. Impact of Rhizobium and PSB inoculation on Peconomy, symbiotic parameters and yield of lentil (Lens culinaris Medikus). J. Res. Punjab Agri. Univ. 45: 1-3.

Khan, H., F. Ahmad, S.Q. Ahmad, M. Sherin and A. Bari. 2006. Effect of phosphorus fertilizer on grain yield of lentil. Sarhad J. Agric. 22: 433-436.

Khanam, M., M.S. Islam, M.H. Ali, I.F. Chowdhury and S.M. Masum. 2016. Performance of soybean under different levels of phosphorus and potassium. Bangladesh Agron. J. 19: 99108.

Maqsood, M., M.S.I. Zamir, R. Ali, A. Wazid and N. Yousaf. 2000. Effect of different phosphorous levels on growth and yield performance of lentil (Lens culinaris Medik). Pakistan J. Biol. Sci. 3: 523-524.

Patil, B.L., V.S. Hegde and P.M. Salimath. 2003. Studies on genetic divergence over stress and non-stress environment in mungbean. Indian J. Gen. Plant Breed. 63(1): 77-78.

Rasheed, M., G. Jilani, I.A. Shah, U. Najeeb and T. Iqbal. 2010. Improved lentil production by utilizing genetic variability in response to phosphorus fertilization. Soil Plant Sci. 60: 485493.

Rashid, M.A., T.M.B. Hossain, M.E. Hoque, M.M. Rahman and K.S. Rahman. 2018. Adoption of lentil varieties in Bangladesh: an expert elicitation approach. Bangladesh J. Agril. Res. 43(1): 159-168.

Sarker, B.C. and J.L. Karmoker. 2009. Effects of phosphorus deficiency on the root growth of lentil seedlings (Lens culinaris Medik) grown in rhizobox. Bangladesh J. Bot. 38: 215-218.

Saxena, K.K. and V.S. Varma. 1996. Effect of N, P and K on the growth of yield of lentil (Lens culinaris). Indian J. Agron. 40(2): 249-242.

Sharma, B.C. and S.C. Sharma 2004. Integrated nutrient management in lentil. Adv. Plant Sci. 17: 195-197.

Shil, N.C., M.A. Saleque, M.R. Islam and M. Jahiruddin. 2016. Soil fertility status of some of the intensive crop growing areas under major agro-ecological zones of Bangladesh. Bangladesh J. Agril. Res. 41(4): 735-757.

Singh, K.K., C. Srinivasarao and M. Ali. 2005. Root growth, nodulation, grain yield, and phosphorus use efficiency of lentil as influenced by phosphorus, irrigation, and inoculation. Commun. Soil Sci. Plan. 36: 1919-1929. 
Singh, N. and G. Singh. 2016. Response of lentil (Lens culinaris Medikus) to phosphorus-A review. Agric. Rev. 37(1): 27-34.

Singh, O.N., M. Sharma and R. Dash. 2003. Effect of seed rate, phosphorus and FYM application on growth and yield of bold seeded lentil. Indian J. Pulses Res. 16: 116-118.

Zeidan, M.S. 2007. Effect of organic manure and phosphorus fertilizers on growth, yield and quality of lentil plants in sandy soil. Res. J. Agric. Biol. Sci. 3(6): 748-752. 